\title{
Üniversite Öğrencilerinin Akademik Başarısını Etkileyen Faktörler: Tarım Ekonomisi Bölümü Örneği
}

\author{
Görkem ÖRÜK ${ }^{1 *}$, Sait ENGINDENIZ ${ }^{2}$ \\ ${ }^{1}$ Siirt Üniversitesi, Ziraat Fakültesi, Tarım Ekonomisi Bölümü, Siirt, TÜRKIYYE \\ ${ }^{2}$ Ege Üniversitesi, Ziraat Fakültesi, Tartm Ekonomisi Bölümü, İzmir, TÜRKIYE
}

\begin{tabular}{ll}
\hline \multicolumn{1}{c}{ Geliş Tarihi/Received: 24.02 .2021} & Kabul Tarihi/Accepted: 04.06.2021 \\
\hline ORCID ID (Yazar sirasına göre / by author order) & \\
(D) orcid.org/0000-0003-3767-0537 (D) orcid.org/0000-0002-7371-3330 \\
"Sorumlu yazar/Corresponding Author: gorkem.ozturk@siirt.edu.tr
\end{tabular}

Öz: Bu çalışma, Siirt Üniversitesi Ziraat Fakültesi Tarım Ekonomisi Bölümü’nde öğrenim gören öğrencilerin demografik ve sosyo-ekonomik yapılarını ve akademik başarılarını etkileyen faktörleri ortaya koymayı amaçlamaktadır. Bu amaç doğrultusunda, Siirt Üniversitesi Ziraat Fakültesi Tarım Ekonomisi Bölümü’nde öğrenim gören 80 öğrenci ile anket çalışması yapılmıştır. Anket çalışmaları 2018-2019 eğitim-öğretim yılının Kasım ayında gerçekleştirilmiştir. Verilerin analizinde tanımlayıcı istatistik yöntemleri, Ki-kare analizi ve Lojistik regresyon analizinden yararlanılmıştır. Öğrencilerin \% 68.75 'inin ilk tercihinin Tarım Ekonomisi Bölümü olduğu ve tercih işlemini yaparken \% 60'nın Tarım Ekonomisi Bölümü hakkında bilgi sahibi olduğu belirlenmiştir. Öğrencilerin çoğunluğu (\% 63.75) istekli olarak Tarım Ekonomisi Bölümü’ne geldiklerini bildirmişlerdir. Lojistik regresyon modelinden elde edilen sonuçlara göre, öğrencilerin akademik başarısını sınıf düzeyi, barınma yeri, ailenin tarımla uğraşma durumu ve devam durumu etkilemektedir. Öğrencilerin yetenek ve ilgi alanlarına göre tercih yapması, üniversitenin sosyal olanaklarının çoğaltılması ve kültürel faaliyetlerinin çeşitlendirilmesi ile öğrencilerin üniversite eğitiminde daha istekli ve daha başarılı olmaları sağlanabilir.

Anahtar Kelimeler: Üniversite eğitimi, öğrenci, akademik başarı, lojistik regresyon, ki-kare analizi, tutum analizi

\section{Factors Affecting the Academic Achievement of University Students: A Case Study for the Department of Agricultural Economics}

\begin{abstract}
This study aims to reveal the demographic and socio-economic structure and the factors influencing the academic success of the students at the Siirt University, Faculty of Agriculture, Department of Agricultural Economics. For this purpose, a survey was conducted with 80 students studying at Siirt University, Faculty of Agriculture, Department of Agricultural Economics. Survey studies were carried out in November of the 2018-2019 academic year. Descriptive statistical methods, Chi-square analysis, and Logistic regression analysis were used to analyze the data. It was determined that the first choice of $68.75 \%$ of the students was the Department of Agricultural Economics, and $60 \%$ of them had knowledge about the Department of Agricultural Economics while making the choice. Most of the students $(63.75 \%)$ stated that they came to the Department of Agricultural Economics willingly. According to the results obtained from the Logistic Regression model, factors affecting the academic success of students are class level, place of residence, family's agriculture status, and attendance. Students can be more eager and more successful in university education by making choices according to their abilities and interests, increasing the university's social facilities, and diversifying its cultural activities.
\end{abstract}

Keywords: University education, student, academic success, logistic regression, chi-square analysis, attitude analysis 


\section{Giriş}

Başarı, okul ortamında belirli bir ders ya da akademik programdan bireyin ne derece yararlandığının bir ölçüsü ya da göstergesidir. Okuldaki başarı ise bir akademik programdaki derslerden öğrencinin aldığı notların ya da puanlarının ortalaması olarak düşünülebilmektedir (Özgüven, 1974).

Üniversite öğrencilerinin akademik başarısını etkileyen çok sayıda faktör bulunmaktadır. Öğrencilerin başarı performanslarını etkileyen içsel ve dişsal faktörler; öğrenciye bağlı faktörler (öğrencilerin demografik, sosyo-ekonomik, kişisel, psikolojik ve sağlık değişkenlerini içeren bilişsel ve iletişimsel tutum ve davranış değişkenleri), öğretim üyesine bağlı faktörler (dersin sunuş şekli, bilgi aktarabilme, motivasyon sağlayabilme, dersin faydalı olduğuna inandırma ve dersi sevdirme yeteneğini içeren öğrencilerle iletişim ve onların bilgi ve becerilerini etkin bir şekilde ölçebilme kabiliyeti ve uygulama değişkenleri) ve çevresel değişkenlere dayalı faktörler (dersliklerin ergonomik özellikleri ve donanımı, gözetmelerin tutum ve davranışları ve sınav sistemi ve uygulamaların etkilerini içeren değişkenler) olmak üzere üç ana grupta incelenmektedir (Topçu ve Uzundumlu, 2012). Üniversite okuyan öğrencilerin birçoğu, yılsonu itibariyle başarısızlığa uğrayabilmektedir. Öğrencilerin başarısızlığının önlenmesi, başarıyı etkileyen faktörlerin belirlenmesine bağlıdır. Başarıyı etkilemede önemli olan faktörler bilinirse başarısızlığı doğuran nedenlerin kontrol altına alınabileceği düşünülmektedir (Özgüven, 1974).

Öğrenci başarısını etkileyen faktörleri belirlemek üzere yapılmış çok sayıda çalışma bulunmaktadır. Rençber (2012), öğrenci başarısı ile derse devam sayısı arasında güçlü, öğrenci başarısı ile lise not ortalaması arasında düşük bir ilişkinin olduğunu bildirmiştir. Topçu ve Uzundumlu (2012), Atatürk Üniversitesi Ziraat Fakültesi'nde eğitim gören öğrencilerin başarısızlığına etki eden faktörleri; kavramsal ve iletişimsel motivasyon zorlukları, rasyonel ders çalışma becerisinden yoksun olma, yanlış alan tercihi ve gelecek kaygısı, fakülte fiziki imkanlarının yetersizliği, negatif duyusal güdüler, ders çıktı hedeflerinden sapma gösteren yanlış ölçüm teknikleri, alan derslerinde uygulama yetersizliği, bilişsel ve davranışsal iletişim eksikliği olarak sıralamışladır. Ağır ve ark. (2016), Kahramanmaraş Sütçü İmam Üniversitesi Ziraat Fakültesi öğrencilerinin öğrenim başarısını etkileyen faktörleri; cinsiyet, mezun olunan lise türü, daha önce bitirilen yüksekokul programı ve annenin çalışma durumu olarak saptamışlardır. Özcan ve ark. (2017) mühendislik fakültesi mezunlarının akademik başarıları üzerine yaptıkları araştırmalarında, mezunların genel mezuniyet başarısının her bölüm için bölüme giriş şekli, cinsiyet, öğretim türü, mezuniyet dönemi gibi değişkenlere bağlı olarak farklı olduğunu rapor etmişlerdir. Toprak ve ark. (2017) Akdeniz Üniversitesi Teknik Bilimler Meslek Yüksekokulu ikinci sınıf öğrencileri ile yaptıkları çalışmada, gelecek ile ilgili hedeflerini netleştirmiş, farklı alanlardaki öğrenci gruplarıyla iletişim halinde olan ve kulüp çalıșmalarıyla bir amaç doğrultusunda hareket eden öğrencilerin daha başarılı olduğunu; Can ve ark. (2018), öğrenci ders başarısını ders tekrar sayısının yanı sıra öğrencilerin mesleki gelişimlerini arttıran, öğrencilere yeni bakış açıları kazandıran uygulamaların daha çok etkilediğini bildirmişlerdir.

Literatürdeki bu sonuçlar dikkate alındığında, farklı eğitim kurumlarında öğrencilerin başarısını etkileyen faktörlerin değişkenlik göstereceği söylenebilir. Bu nedenle, bu yöndeki araştırmaların yapılması, elde edilen sonuçların eğitim programlarının hazırlanmasında değerlendirilmesi açısından önemli katkı sağlayacağ düşünülmektedir.

Bu çalışmada, Siirt Üniversitesi Ziraat Fakültesi Tarım Ekonomisi Bölümü öğrencilerinin, demografik ve sosyo-ekonomik yapıları, bölümü tercih etme nedenleri, bölümde aldıkları eğitimden memnuniyet durumları da incelenerek akademik başarılarını etkileyen faktörlerin belirlenmesi amaçlanmıştır.

\section{Materyal ve Yöntem}

Çalışmanın ana materyalini; Siirt Üniversitesi, Ziraat Fakültesi, Tarım Ekonomisi Bölümü öğrencilerinden anket yöntemiyle elde edilen veriler oluşturmuştur. Çalışmada tam sayım yöntemi kullanılarak Tarım Ekonomisi Bölümü'nde öğrenim gören toplam 116 öğrenci çalışma kapsamına alınmıştır. Ancak anket yapıldı ̆̆1 dönemde bazı öğrenciler derslere katılmadığ 1 için kapsam dışı kalmış ve 80 öğrenci ile anket çalışması tamamlanmıştır. Araştırmanın yapıldığı dönemde Tarım Ekonomisi Bölümü’nde dördüncü sınıf öğrencisi olmadı̆̆ı için, araştırma kapsamına birinci, ikinci ve üçüncü sınıf öğrencileri alınmıştır.

Anket çalışmaları 2018-2019 eğitim-öğretim yılının Kasım ayında gerçekleştirilmiştir. Hazırlanan anket formlarında; öğrencilerin demografik ve sosyo-ekonomik özelliklerinin yanı sıra, bölüm tercihleri, ders tutumları, üniversite ve Tarım Ekonomisi Bölümü memnuniyetleri ile ilgili sorular yer almıştır. 
Verilerin analizinde, frekans ve yüzde gibi tanımlayıcı istatistikler kullanılmıştır. Elde edilen verilerde değişkenler arasındaki ilişkilerin tespit edilmesinde Ki-kare analizinden yararlanılmıştır. Tutumlar, davranışları açıklayıcı bir değişken olarak görülmekte ve bu nedenle ölçülmesi büyük önem taşımaktadır. Çünkü bir insanın tutumunun bilinmesi sayesinde, gelecek davranışlarının ölçülebileceği varsayımında bulunulmaktadır (Engindeniz ve Özden, 2009). Öğrencilerin memnuniyet durumlarının ve derslere yönelik tutumları 5'li Likert ölçeği ile ölçülmüştür.

Öğrencilerin akademik başarısını etkileyen faktörlerin saptanmasında Lojistik regresyon analizinden yararlanılmıştır. Modelde cinsiyet, sınıf, barınma yeri, mezun olunan lise, annenin ve babanın eğitim düzeyi, ailenin tarımla uğraşma durumu, derslere devam durumu ve Tarım
Ekonomisi Bölümü'nden memnun olma durumu değişkenleri ele alınmış ve bunlardan hangi değişkenlerin öğrencilerin akademik başarısında etkili olduğu incelenmiştir. Modelde kullanılan değişkenler Tablo 1'de sunulmuştur. Siirt Üniversitesi "Lisans Eğitim-Öğretim ve Sinav Yönetmeliği” dikkate alınarak; not ortalaması 0 ile 1.99 arasında olan öğrenciler "başarısız", not ortalaması 2.00 ve üzeri olan öğrenciler ise "başarılı" olarak değerlendirilmiştir.

Lojistik regresyon analizinde amaç, kategorik bağımlı değişkenin değerini tahmin etmek olduğundan, aslında burada yapılmaya çalışılan iki ya da daha fazla gruba ilişkin üyelik tahminidir. Buna göre analizin amaçlarından birinin sınıflandırma, diğerinin ise bağımlı ve bağımsız değişkenler arasındaki ilişkileri araştırmak olduğu ifade edilebilir (Çokluk, 2010).

Tablo 1. Lojistik regresyon modelinde kullanılan değişkenler

Table 1. Variables used in the logistic regression model

\begin{tabular}{|c|c|}
\hline \multicolumn{2}{|l|}{ Bağımlı değişken } \\
\hline Başarı durumu & 0: Başarısız, 1: Başarılı \\
\hline \multicolumn{2}{|l|}{ Bağımsız değişkenler } \\
\hline Cinsiyet $(\mathrm{C} 1)$ & 1: Erkek 2: Kadın \\
\hline \multirow{3}{*}{ Sinif (C3) } & 1: 1.sinif \\
\hline & 2: 2.sinif \\
\hline & 3: 3.sinif \\
\hline \multirow[t]{4}{*}{ Barınma yeri (C4) } & 1: Öğrenci evi \\
\hline & 2: Devlet yurdu \\
\hline & 3: Özel yurt \\
\hline & 4: Aile yanı \\
\hline \multirow[t]{7}{*}{ Mezun olunan lise (C5) } & 1: Genel Lise \\
\hline & 2: Anadolu Lisesi \\
\hline & 3: Süper Lise \\
\hline & 4: Fen Lisesi \\
\hline & 5: Meslek Lisesi \\
\hline & 6: İmam Hatip Lisesi \\
\hline & 7: Özel Lise \\
\hline \multirow[t]{6}{*}{ Annenin eğitim düzeyi (C10) } & 1: Okur-yazar değil \\
\hline & 2: Okur-yazar \\
\hline & 3: İlkokul \\
\hline & 4: Ortaokul \\
\hline & 5: Lise \\
\hline & 6: Üniversite \\
\hline \multirow[t]{8}{*}{ Babanın eğitim düzeyi (C11) } & 1: Okur-yazar değil \\
\hline & 2: Okur-yazar \\
\hline & 3: İlkokul \\
\hline & 4: Ortaokul \\
\hline & 5: Lise \\
\hline & 6: Yüksekokul \\
\hline & 7: Üniversite \\
\hline & 8: Lisansüstü \\
\hline \multirow[t]{2}{*}{ Ailenin tarımla uğraşma durumu (C12) } & 1: Evet \\
\hline & 2: Hayır \\
\hline \multirow[t]{2}{*}{ Derslere düzenli gelme durumu (C19) } & 1: Evet \\
\hline & 2: Hayır \\
\hline \multirow[t]{2}{*}{ Tarım Ekonomisi Bölümü’nde öğrenim görmekten memnun musunuz? (C30) } & 1: Evet \\
\hline & 2: Hayır \\
\hline
\end{tabular}


Lojistik regresyon modelinde bağımlı değişken kesiklidir ve tahmin edilen olasılık değerler 0 ile 1 arasında değişmektedir. Lojistik regresyon modeli Eşitlik 1 ile ifade edilmektedir (Gujarati, 1992).

$$
\begin{aligned}
& \quad L_{i}=\ln \left[\frac{P_{i}}{\left(1-P_{i}\right)}\right]=z_{i}=\alpha+\beta_{1} X_{1}+\beta_{2} X_{2}+ \\
& \cdots+\beta_{n} X_{n}
\end{aligned}
$$

Eşitlikte $L_{i}$, bağımlı değişkeni; $P_{i}$, istenilen olayın olma olasılığını; $1-P_{i}$, istenmeyen olayın olma olasılığını; $\alpha$, sabit katsayıyı; $\beta_{i}$, her bir bağımsız değişken için tahmin edilecek parametreyi; $X_{i}$, i'inci bağımsız değişkeni ifade etmektedir.

Lojistik regresyon analizinde, incelenen bir olayın olasılığının kendi dışında kalan diğer olayların olasılığına oranına Odds değeri, incelenen iki farklı olayın Odds değerlerinin birbirine oranına ise Odds oranı denir (Girginer ve Cankuş, 2008). Katsayıların doğruluğunun yorumlanmasında -2 log likehood, Cox\&Snell R ${ }^{2}$, Nagelkerke $\mathrm{R}^{2}$ sayıları kullanılmaktadır. Bunun yanı sıra birimlerin veya bireylerin ne kadar doğru sınıflandırıldığının tespiti; doğru sınıflandırma yüzdesi, Hosmer-Lemeshow testi ve Omnibus testi ile değerlendirilmektedir (Akbulut ve Rençber, 2015).

\section{Bulgular ve Tartışma}

Öğrencilerin demografik ve sosyo-ekonomik özellikleri Tablo 2'de sunulmuştur. Ankete katılan öğrencilerin \% 62.50’sinin kadın, \% 37.50’sinin erkek olduğu görülmektedir. Öğrencilerin yaş ortalaması 26.60 y1l olarak hesaplanmıştır. Öğrencilerin bir bölümü unvan değişikliği amaciyla Tarım Ekonomisi Bölümü'nü tercih ettiği için yaş ortalaması yüksektir. Ankete katılan öğrencilerin \% 46.25'i üçüncü sınıf öğrencisi, \% 37.50'si ikinci sınıf öğrencisi ve \% $16.25^{\prime} \mathrm{i}$ birinci sınıf öğrencisidir. Öğrencilerin \% 33.75'i Genel liseden, $\%$ 28.75'i Anadolu Lisesi'nden, \% 22.50'si Meslek Lisesi'nden ve \% 15'i diğer liselerden (Süper Lise, İmam Hatip lisesi, Özel Lise) mezun olmuştur. Öğrencilerin barınma yerleri incelendiğinde; $\%$ 60'ının aile yanında, \% 17.50'sinin devlet yurdunda, \% 13.75'inin öğrenci evinde ve $\%$ 8.75'inin özel yurtta kaldığı görülmektedir. Öğrencilerin aylık ortalama geliri 1873.53 TL olarak hesaplanmıştır (Tablo 2).

Ankete katılan öğrencilerin ailelerinin büyük çoğunluğu (\% 71.25) il merkezinde ve \% 88.75'i Güneydoğu Anadolu Bölgesi'nde ikamet etmektedir (Tablo 2). Benzer şekilde Iğdır Üniversitesi Tarım Ekonomisi Bölümü öğrencileri ile yapılan çalışmada (Karadaş ve ark., 2016), öğrencilerin \% 75.9'unun Doğu ve Güneydoğu Anadolu Bölgesi'nden geldiği saptanmıştır.
Araştırma kapsamındaki öğrencilerin \% 45'i annesinin ilkokul mezunu olduğunu, \% 28.75'i annesinin okur-yazar olmadığını, \% $36.25^{\prime}$ i babasının ilkokul mezunu, \% 21.25'i babasının lise mezunu olduğu ifade etmiştir (Tablo 2). Buna göre öğrencilerin ailelerinin eğitim düzeylerinin düşük olduğu söylenebilir. Sarıhan ve ark. (2015), tarafından Uşak Üniversitesi Ziraat ve Doğa Bilimleri Fakültesi'nde yapılan çalışmada da aynı şekilde öğrencilerin anne-babalarının eğitim düzeylerinin düşük olduğu bildirilmiştir.

$\mathrm{Bu}$ araştırmanın diğer sonuçlarına göre ankete katılan öğrencilerin \% 55'inin ailesinin tarımla uğraştığ $1, \quad \% \quad 76.25^{\prime} \mathrm{i}$ sigara kullanmadığ1, \% 67.50'si sosyal ve kültürel faaliyetlere katıldığı, $\%$ 81.25'i bilgisayar kullanabildiği \% 51.25'inin İngilizce seviyesinin kötü durumda olduğu tespit edilmiştir (Tablo 2).

Araştırma sonucunda elde edilen bulgulara göre, Tarım Ekonomisi Bölümü, öğrencilerin \% 68.75'inin ilk tercihi olduğu anlaşılmıştır. Tercih işlemini yaparken Tarım Ekonomisi Bölümü hakkında bilgi sahibi olduğunu söyleyenlerin oranı $\%$ 60, meslek hakkında bilgi sahibi olduğunu söylerin oranı \% 58.75' dir. Öğrencilerin \% 63.75'i istekli olarak bölüme geldiklerini ifade etmiştir (Tablo 3). Bu oranın yüksek olmasında unvan değişikliği amacıyla gelen öğrencilerin etkisi bulunmaktadır. Sezgin ve ark. (2008) tarafindan yapılan çalışmada, bu araştırmadan farklı olarak Atatürk Üniversitesi Ziraat Fakültesi'nde öğrenim gören öğrencilerin büyük bir kısmının (\% 53.6) fakülteye istemeyerek geldikleri belirlenmiştir. $\mathrm{Bu}$ çalışma ile uyumlu olarak ise Demir ve ark. (2014), Atatürk Üniversitesi Ziraat Fakültesi Tarım Ekonomisi Bölümü'nde yaptıkları çalışmada, öğrencilerin \% 69'unun Tarım Ekonomisi Bölümü'nü isteyerek tercih ettiklerini bildirmişlerdir.

İsteyerek Tarım Ekonomisi Bölümü’ne gelen öğrencilerin \% 27.45'i unvan değişikliği, \% 17.65'i ailesi tarımla uğraştığ 1 için ve ilgi alanı olduğu için, $\%$ 15.67'si Ziraat Mühendisi olmak istediği için, \% 13.72'si eşit ağırlık ile bölüme girildiği için, \% 5.88'i akademik kariyer için ve \% 1.96'sı polis olmak için Tarım Ekonomisi Bölümü'nü tercih ettiğini belirtmiştir (Tablo 3). Demir ve ark. (2006) tarafından yapılan araştırmada öğrencilerin \% 75'inin açıkta kalmamak için, Kızılaslan ve ark. (2017) tarafından yapılan çalışmada ise öğrencilerin \% 35.0'ının açıkta kalmamak ve \% 29.3'ünün ise idealindeki meslek olduğu için Ziraat Fakültesi'ni tercih ettikleri saptanmıştır.

Tercihlerini hazırlarken öğrencilerin \% 42.50'sinde ailesinin etkisi olduğu, \% 40'ının hiç kimsenin etkisi olmadı̆̆ 1 , 17.50 'sinde ise diğer 
Tablo 2. Öğrencilerin demografik ve sosyo-ekonomik özellikleri Table 2. Demographic and socioeconomic characteristics of students

\begin{tabular}{|c|c|c|c|}
\hline Özellikler & & Say1 & $\%$ \\
\hline \multirow{2}{*}{ Cinsiyet } & Kadın & 30 & 37.50 \\
\hline & Erkek & 50 & 62.50 \\
\hline \multirow{3}{*}{ Sinif } & 1.sinif & 13 & 16.25 \\
\hline & 2.sinif & 30 & 37.50 \\
\hline & 3.sinif & 37 & 46.25 \\
\hline \multirow{4}{*}{ Barınma yeri } & Öğrenci evi & 11 & 13.75 \\
\hline & Devlet yurdu & 14 & 17.50 \\
\hline & Özel yurt & 7 & 8.75 \\
\hline & Aile yanı & 48 & 60.00 \\
\hline \multirow{6}{*}{ Mezun olunan lise } & Genel Lise & 27 & 33.75 \\
\hline & Anadolu Lisesi & 23 & 28.75 \\
\hline & Süper Lise & 1 & 1.25 \\
\hline & Meslek Lisesi & 18 & 22.50 \\
\hline & İmam Hatip Lisesi & 6 & 7.50 \\
\hline & Özel Lise & 5 & 6.25 \\
\hline \multirow{3}{*}{ Ailenin yaşadığ yer } & İl merkezi & 57 & 71.25 \\
\hline & İlçe merkezi & 10 & 12.50 \\
\hline & Kasaba/köy & 13 & 16.25 \\
\hline \multirow{5}{*}{ Ailenin yaşadığı bölge } & Güneydoğu Anadolu & 71 & 88.75 \\
\hline & Doğu Anadolu & 4 & 5.00 \\
\hline & Akdeniz & 2 & 2.50 \\
\hline & Ege & 1 & 1.25 \\
\hline & Yurtdiș1 & 2 & 2.50 \\
\hline \multirow{5}{*}{ Öğrencinin aylık geliri (TL) } & $<250 \mathrm{TL}$ & 7 & 8.75 \\
\hline & $251-500 \mathrm{TL}$ & 29 & 36.25 \\
\hline & $501-1000 \mathrm{TL}$ & 17 & 21.25 \\
\hline & $1001-2500 \mathrm{TL}$ & 5 & 6.25 \\
\hline & $>2501 \mathrm{TL}$ & 22 & 27.50 \\
\hline \multirow{6}{*}{ Anne eğitim düzeyi } & Okur-yazar değil & 23 & 28.75 \\
\hline & Okur-yazar & 3 & 3.75 \\
\hline & İlkokul & 36 & 45.00 \\
\hline & Ortaokul & 10 & 12.50 \\
\hline & Lise & 5 & 6.25 \\
\hline & Üniversite & 3 & 3.75 \\
\hline \multirow{8}{*}{ Baba eğitim düzeyi } & Okur-yazar değil & 4 & 5.00 \\
\hline & Okur-yazar & 6 & 7.50 \\
\hline & İlkokul & 29 & 36.25 \\
\hline & Ortaokul & 10 & 12.50 \\
\hline & Lise & 17 & 21.25 \\
\hline & Yüksekokul & 3 & 3.75 \\
\hline & Üniversite & 9 & 11.25 \\
\hline & Lisansüstü & 2 & 2.50 \\
\hline \multirow{2}{*}{ Ailenizde tarım ile uğraşan var mı? } & Evet & 44 & 55.00 \\
\hline & Hayır & 36 & 45.00 \\
\hline \multirow{2}{*}{ Sigara kullaniyor musunuz? } & Evet & 19 & 23.75 \\
\hline & Hayır & 61 & 76.25 \\
\hline \multirow{2}{*}{ Kültürel, sosyal, sportif faaliyetlere katılıyor musunuz? } & Evet & 54 & 67.50 \\
\hline & Hayır & 26 & 32.50 \\
\hline \multirow{2}{*}{ Bilgisayar programı kullanıyor musunuz? } & Evet & 65 & 81.25 \\
\hline & Hayır & 15 & 18.75 \\
\hline \multirow{4}{*}{ İngilizce seviyesi } & Kötü & 41 & 51.25 \\
\hline & Orta & 32 & 40.00 \\
\hline & İyi & 6 & 7.50 \\
\hline & Çok iyi & 1 & 1.25 \\
\hline
\end{tabular}


Tablo 3. Öğrencilerin bölüm tercihlerine ilişkin bazı bilgiler ve memnuniyet durumları

Table 3. Some information about department preferences and satisfaction level of students

\begin{tabular}{|c|c|c|c|}
\hline & & Say1 & $\%$ \\
\hline \multirow{6}{*}{ Tarım Ekonomisi Bölümü tercih sırası } & İlk tercih & 55 & 68.75 \\
\hline & İkinci tercih & 6 & 7.50 \\
\hline & Üçüncü tercih & 5 & 6.25 \\
\hline & Dördüncü tercih & 3 & 3.75 \\
\hline & 5.- 23. tercih & 9 & 11.25 \\
\hline & Son tercih & 2 & 2.50 \\
\hline \multirow{2}{*}{$\begin{array}{l}\text { Tarım Ekonomisi Bölümü hakkında bilgisi olma } \\
\text { durumu }\end{array}$} & Evet & 48 & 60.00 \\
\hline & Hayır & 32 & 40.00 \\
\hline \multirow{2}{*}{ Meslek hakkında bilgisi olma durumu } & Evet & 47 & 58.75 \\
\hline & Hayır & 33 & 41.25 \\
\hline \multirow{2}{*}{$\begin{array}{l}\text { Tarım Ekonomisi Bölümü'nü isteyerek tercih etme } \\
\text { durumu }\end{array}$} & Evet & 51 & 63.75 \\
\hline & Hayır & 29 & 36.25 \\
\hline \multirow{7}{*}{ İsteyerek tercih ettiyse nedeni } & Unvan değişikliği için & 14 & 27.45 \\
\hline & Ziraat Mühendisi olmak istediği için & 8 & 15.67 \\
\hline & Aile tarımla uğraştığ 1 için & 9 & 17.65 \\
\hline & Eşit ağırlık ile kazanıldığ 1 için & 7 & 13.72 \\
\hline & İlgi alanı olduğu için & 9 & 17.65 \\
\hline & Akademik kariyer için & 3 & 5.88 \\
\hline & Polis olmak için & 1 & 1.96 \\
\hline \multirow{4}{*}{ İsteyerek tercih etmediyse nedeni } & Aile isteği & 17 & 58.62 \\
\hline & Son tercih & 2 & 6.90 \\
\hline & Bilgi sahibi değildim & 2 & 6.90 \\
\hline & Cevap yok & 8 & 27.58 \\
\hline \multirow{2}{*}{ Tekrar tercih etme durumu } & Evet & 39 & 48.75 \\
\hline & Hayır & 41 & 51.25 \\
\hline \multirow{5}{*}{ Tekrar tercih etmeme nedeni } & Zor & 14 & 34.15 \\
\hline & Sayısal ağırlıklı & 6 & 14.63 \\
\hline & Başka bölüm istiyor & 13 & 31.70 \\
\hline & İş imkanları k1sıtlı & 5 & 12.19 \\
\hline & Tekrara gerek yok & 3 & 7.32 \\
\hline \multirow{5}{*}{ Tercih etmede etkili olan kişiler } & Hiç kimse & 32 & 40.00 \\
\hline & Aile & 34 & 42.50 \\
\hline & Arkadaşlar & 7 & 8.75 \\
\hline & Öğretmenler & 1 & 1.25 \\
\hline & Akrabalar & 6 & 7.50 \\
\hline \multirow{5}{*}{ Mezun olduktan sonra planı } & Kamu sektöründe çalışmak & 40 & 50.00 \\
\hline & Özel sektörde çalışmak & 7 & 8.75 \\
\hline & Lisansüstüne devam etmek & 17 & 21.25 \\
\hline & Planım yok & 5 & 6.25 \\
\hline & Kendi işini kurmak & 11 & 13.75 \\
\hline \multirow{2}{*}{$\begin{array}{l}\text { Tarım Ekonomisi Bölümü'nde okumaktan memnun } \\
\text { olma durumu }\end{array}$} & Evet & 47 & 58.75 \\
\hline & Hayır & 33 & 41.25 \\
\hline \multirow{2}{*}{ Üniversiteden memnun olma durumu } & Evet & 23 & 28.75 \\
\hline & Hayır & 57 & 71.25 \\
\hline \multirow{2}{*}{ Üniversitenin bulunduğu ilden memnun olma durumu } & Evet & 32 & 40.00 \\
\hline & Hayır & 48 & 60.00 \\
\hline \multirow{2}{*}{ Derslere düzenli olarak geliyor musunuz? } & Evet & 66 & 82.50 \\
\hline & Hayır & 14 & 17.50 \\
\hline
\end{tabular}

kişilerin (arkadaş, öğretmen, akraba) etkisi olduğu saptanmıştır. Ayrıca görüşülen öğrencilerin \% 58.75'i Tarım Ekonomisi Bölümü'nde okumaktan memnun iken, \% 71.25'i üniversiteden ve \% 60’1 üniversitenin bulunduğu ilden memnun değildir. Öğrencilerin \% 82.50'si derslere düzenli devam etmekte olup, öğrencilerin genel not ortalamas1 2.47 'dir. Öğrencilerin mezun olduktan sonra \% 50'sinin kamu sektöründe çalışmayı, $\%$ 21.25'inin lisansüstü eğitime devam etmeyi, \% 13.75'inin kendi işini kurmayı, \% 8.75'inin özel sektörde çalışmayı planladı̆̆ı ve \% $6.25^{\prime}$ 'inin herhangi bir planı olmadığı görülmektedir (Tablo 3). 
Tarım Ekonomisi Bölümü'nü kendi isteğiyle tercih etmeyenlerin \% 58.62'si ailesinin isteği doğrultusunda bölümü tercih etmek durumunda kaldıklarını ifade etmiştir. Bununla birlikte görüşülen öğrencilerin \% 51.25'i Tarım Ekonomisi Bölümü'nü tekrar tercih etmeyeceğini ve tercih etmeme nedeni olarak \% 34.15'i Tarım Ekonomisi Bölümü'nün zor olduğunu, \% 31.70'i başka bir bölümde okumak istediğini, \% 14.63'ü sayısal ağırlıklı bir bölüm istemediğini, \% 12.19'u iş imkanlarının kisitlı olması ve \% 7.32'si tekrar etmenin gereği olmadığgnı belirtmişlerdir (Tablo 3).

Öğrencilerin Tarım Ekonomisi Bölümü'nü isteyerek tercih etme durumu ile cinsiyet ve mezun olunan lise türü arasında anlamlı bir ilişkinin olmadığ1 saptanmıştır $(\mathrm{p}>0.05)$. Araştırmada, Tarım Ekonomisi Bölümü'ne isteyerek gelme durumu ile tercihlerinde etkili olan kişiler arasında istatistiksel olarak anlamlı bir ilişki olmadığı saptanmıştır $\quad(\mathrm{p}>0.05)$ Tarım Ekonomisi Bölümü'ne isteyerek gelme durumu ile Tarım Ekonomisi Bölümü'nden memnun olma durumu arasında istatistiksel olarak anlamlı bir ilişki olduğu saptanmıştır $(\mathrm{p}<0.05)$ (Tablo 4).

Öğrencilerinin cinsiyeti ve sınıf düzeyi ile mezun olduktan sonraki planları arasında istatistiksel olarak anlamlı bir ilişki olduğu saptanmıştır $(\mathrm{p}<0.05)($ Tablo 5). Tekirdağ Namık

Tablo 4. Tarım Ekonomisi Bölümü’nü isteyerek tercih etme durumu ile bazı değişkenler arasındaki Ki-Kare analizi sonuçları

Table 4. Chi-Square analysis results of the relationship between willingly choosing the department of Agricultural Economics and some variables

\begin{tabular}{|c|c|c|c|c|c|}
\hline \multirow{3}{*}{ Özellikler } & & \multicolumn{4}{|c|}{ Tarım Ekonomisi Bölümü’nü isteyerek tercih etme durumu } \\
\hline & & \multicolumn{2}{|c|}{ Evet } & \multicolumn{2}{|c|}{ Hayır } \\
\hline & & Say1 & $\%$ & Say1 & $\%$ \\
\hline \multirow{2}{*}{ Cinsiyet } & Erkek & 35 & 68.63 & 15 & 51.72 \\
\hline & Kadın & 16 & 31.37 & 14 & 48.28 \\
\hline p değeri: 0.133 & & & & & \\
\hline \multirow{6}{*}{ Mezun olunan lise } & Genel Lise & 19 & 37.26 & 8 & 27.59 \\
\hline & Anadolu Lisesi & 13 & 25.49 & 10 & 34.48 \\
\hline & Süper Lise & 1 & 1.96 & - & - \\
\hline & Meslek Lisesi & 13 & 25.49 & 5 & 17.24 \\
\hline & İmam Hatip Lisesi & 2 & 3.92 & 4 & 13.79 \\
\hline & Özel Lise & 3 & 5.88 & 2 & 6.90 \\
\hline p değeri: 0.468 & & & & & \\
\hline \multirow{5}{*}{ Tercih etmede etkili olan kişiler } & Aile & 19 & 37.26 & 15 & 51.72 \\
\hline & Arkadaşlar & 6 & 11.76 & 1 & 3.45 \\
\hline & Öğretmenler & - & - & 1 & 3.45 \\
\hline & Akrabalar & 3 & 5.88 & 3 & 10.35 \\
\hline & Hiç kimse & 23 & 45.10 & 9 & 31.03 \\
\hline p değeri:0.237 $\quad X^{2}: 5.536$ & & & & & \\
\hline \multirow{2}{*}{$\begin{array}{l}\text { Tarım Ekonomisi Bölümü'nde } \\
\text { okumaktan memnun olma durumu }\end{array}$} & Evet & 36 & 76.60 & 15 & 45.45 \\
\hline & Hayır & 11 & 23.40 & 18 & 54.55 \\
\hline
\end{tabular}

Tablo 5. Öğrencilerin mezun olduktan sonraki planları ile bazı değişkenler arasındaki Ki-Kare analizi sonuçları

Table 5. Chi-Square analysis results of the relationship between students' plans after graduation and some variables

\begin{tabular}{|c|c|c|c|c|c|c|c|c|c|c|c|}
\hline \multirow{3}{*}{ Özellikler } & & \multicolumn{10}{|c|}{ Mezun olduktan sonraki planlar } \\
\hline & & \multicolumn{2}{|c|}{$\begin{array}{c}\text { Kamu } \\
\text { sektöründe } \\
\text { çalıșmak }\end{array}$} & \multicolumn{2}{|c|}{$\begin{array}{c}\text { Özel } \\
\text { sektörde } \\
\text { çalışmak } \\
\end{array}$} & \multicolumn{2}{|c|}{$\begin{array}{l}\text { Lisansüstüne } \\
\text { devam etmek }\end{array}$} & \multicolumn{2}{|c|}{ Planım yok } & \multicolumn{2}{|c|}{$\begin{array}{l}\text { Kendi işini } \\
\text { kurmak }\end{array}$} \\
\hline & & Say1 & $\%$ & Say1 & $\%$ & Say1 & $\%$ & Say1 & $\%$ & Say1 & $\%$ \\
\hline \multirow{2}{*}{ Cinsiyet } & Erkek & 27 & 67.50 & 6 & 85.71 & 4 & 23.53 & 3 & 60.00 & 10 & 90.91 \\
\hline & Kadın & 13 & 32.50 & 1 & 14.29 & 13 & 76.47 & 2 & 40.00 & 1 & 9.09 \\
\hline p değeri:0.002 & $\mathrm{X}^{2}: 16.853$ & & & & & & & & & & \\
\hline \multirow{3}{*}{ Sinıf düzeyi } & 1 & 3 & 7.50 & 3 & 42.86 & 1 & 5.88 & 3 & 60.00 & 3 & 27.27 \\
\hline & 2 & 13 & 32.50 & 3 & 42.86 & 11 & 64.71 & 1 & 20.00 & 2 & 18.18 \\
\hline & 3 & 24 & 60.00 & 1 & 14.29 & 5 & 29.41 & 1 & 20.00 & 6 & 54.55 \\
\hline
\end{tabular}


Kemal Üniversitesi Ziraat Fakültesi'nde yapılan araştırmada aile mesleği ile mezuniyet sonrası tarımla ilgilenme düşüncesi arasında bir ilişki olduğu saptanmıştır. Buna göre araştırmada ailesi çiftçilikle uğraşan, işçi ve özel sektörde bulunan öğrenciler kesinlikle tarımla ilgilenmek istediği; ailesi emekli, memur ve serbest meslekte çalışan ögrencilerin ise sadece ilgilenmeyi düşündükleri belirlenmiştir (Başaran ve ark., 2019).

Ankete katılan öğrencilerin Tarım Ekonomisi Bölümü'ndeki derslere ilişkin yönelik tutum ve davranışları Likert ölçeğinden yararlanılarak ortaya konulmuştur. Buna göre ortalama puanlar dikkate alındığında, öğrencilerin derslerde anlamadıkları konuları sorduğu $(\bar{X}=3.74)$, dersleri dikkatle dinlediği $(\bar{X}=3.56)$, anlamadıkları konular olduğunda ders dışında öğretim üyesine danıştıkları $(\bar{X}=3.29)$, Tarım Ekonomisi Bölümü'ndeki tüm dersleri sevmedikleri $(\bar{X}=2.20)$ saptanmıştır. Öğrencilerin \% 37.50'si “Lisede yeteri kadar matematik dersi almadığım için bölümde zorlanıyorum" ifadesine, \% 21.25' $\mathrm{i}$ ise "Bölümde bu kadar sayısal ders olduğunu bilseydim tercih etmezdim" ifadesine katılmaktadır (Tablo 6). Bu durum üniversite bölüm tanıtımlarının önemini ortaya çıkarmaktadır. $\mathrm{Bu}$ nedenle bölüm tanıtımlarının daha etkili ve iyi şekilde yapılması gerekmektedir.

Öğrencilerin Tarım Ekonomisi Bölümü'ndeki eğitim-öğretim durumu ile öğretim üyeleri ve üniversite hakkındaki düșünceleri Tablo 7'de verilmiştir. Tablo 7 incelendiğinde; öğrencilerin eğitim-öğretim durumu ile öğretim üyeleri ve üniversite hakkındaki düşüncelerine ilişkin en düşük katılımın gösterildiği ifade "Üniversitenin sosyal olanakları yeterlidir" ( $\bar{X}=1.89)$ ifadesidir. En düşük katılım gösteren diğer ifadeler "Üniversitede öğrenci kulüpleri oldukça etkindir" $(\bar{X}=2.15) \quad$ ve "Üniversitede yeterli sayıda konferans, çalıştay gibi etkinlikler düzenlenmektedir" $\quad(\bar{X}=2.23) \quad$ ifadeleridir. Dolayısıyla üniversitenin sosyal ve kültürel olanaklarının arttırılması oldukça önemlidir. En yüksek katılım gösterilen ifadeler ise sırasıyla, "Öğretim üyeleri dersle ilgili soruları ders sırasında ve ders dişında yanıtlamaktadır" $(\bar{X}=3.97)$, "Öğretim üyelerinin ders notlarına ulaşmakta güçlük yaşamıyorum" $(\bar{X}=3.71)$ ve “Öğretim üyeleri derse hazırlıklı gelmektedir” $(\bar{X}=3.64)$ ifadeleridir. Öğrencilerin "Öğretim üyeleri dersi ilgi çekici hale getirmektedir” $(\bar{X}=2.99)$, "Öğretim üyeleri tüm öğrencilere objektif şekilde yaklaşmaktadır" ( $\bar{X}=2.98)$ ve "Bölümden yeterli mesleki donanıma sahip olarak mezun olacağıma inanıyorum" ( $(\bar{X}=2.85)$ ifadelerinde ise kararsız kaldıkları saptanmıştır. Buna göre öğrencilerin genel olarak Tarım Ekonomisi Bölümü’ndeki öğretim üyelerinden memnun oldukları tespit edilmiştir (Tablo 7).

Lojistik regresyon modeli ile elde edilen sonuçlar Tablo 8'de verilmiştir. Hosmer Lemeshow testi sonucuna göre modelin uyumlu olduğu tespit edilmiştir $(p=0.812>0.05)$. Omnibus testine göre modelin anlamlı olduğu görülmektedir $(p=0.002<0.05)$. Nagelkerke $R^{2}$ istatistiğine göre bağımlı değişken ile bağımsız değişkenler arasında yaklaşık \% 44'lük bir ilişki bulunmaktadır. Cox ve Snell $\mathrm{R}^{2}$ istatistiğine göre ise bağımlı değişken ile bağımsız değișkenler arasında yaklașık \% 28.3'lük bir ilişki olduğu saptanmıştır (Tablo 8). Cox ve Snell $\mathrm{R}^{2}$ değeri $0.20-0.40$ arasında olduğu için yeterince uygun olarak kabul edilebilir. Modelde doğru sınıflandırma yapma oranı \% 81.3 olarak bulunmuştur (Tablo 9).

Elde edilen lojistik regresyon modelinde etkili ve istatistiksel olarak anlamlı bulunan değişkenler sınıf, barınma yeri, ailenin tarımla uğraşma durumu ve devam durumu olarak belirlenmiştir. Modelde yer alan cinsiyet, mezun olunan lise, annenin ve babanın eğitim durumları istatistiksel olarak anlamlı bulunmamıştır (Tablo 8). Çırak (2012), bu araştırmadaki gibi lojistik regresyon analizinden yararlanarak yaptığı araştırmada benzer şekilde mezun olunan lisenin akademik başarıy etkilediğini belirlemiştir. Bahar ve ark. (2009) ve Toprak ve ark. (2017) tarafından yapılan çalışmalarda ise bu çalışmadan farklı olarak cinsiyete göre öğrencilerin akademik başarı durumlarının değiştiğini ve k1z öğrencilerin akademik başarı ortalamasının daha yüksek olduğu bulunmuştur. Ziraat eğitiminde başarıya etki eden faktörlerin belirlenmesi amaciyla Atatürk Üniversitesi Ziraat Fakültesi'nde gerçekleştirilen araştırmada da benzer değişkenler ele alınmıştır. Yapılan araştırmada öğrenci başarısı ile bölümler, cinsiyet, medeni durum, öğrenci seçme sınavından alınan puan, lise not ortalaması, ders çalışma durumu ve derslere devam durumu arasında önemli ve pozitif ilişki olduğunu; sınıf, yaş gurubu, kaldıkları yerler ve mezun oldukları lise türleri arasında ise önemli ve negatif yönde ilişki olduğunu saptamışlardır (Sezgin ve Yavuz, 2008). Kahramanmaraş Sütçü İmam Üniversitesi'nde yapılan bir araştırmada ise Ziraat Fakültesi öğrencilerinin öğrenim başarısında etkili değişkenler; cinsiyet, mezun olunan lise türü, daha önce bitirilen lisans veya yüksekokul programı ve annenin çalışma durumu olarak tespit edilmiştir (Ağır ve ark., 2016).

Lojistik regresyon modelinde yer alan katsayılar incelendiğinde, sınıf değişkeninin katsayısı pozitif olup $\% 5$ anlam düzeyinde istatistiksel olarak 


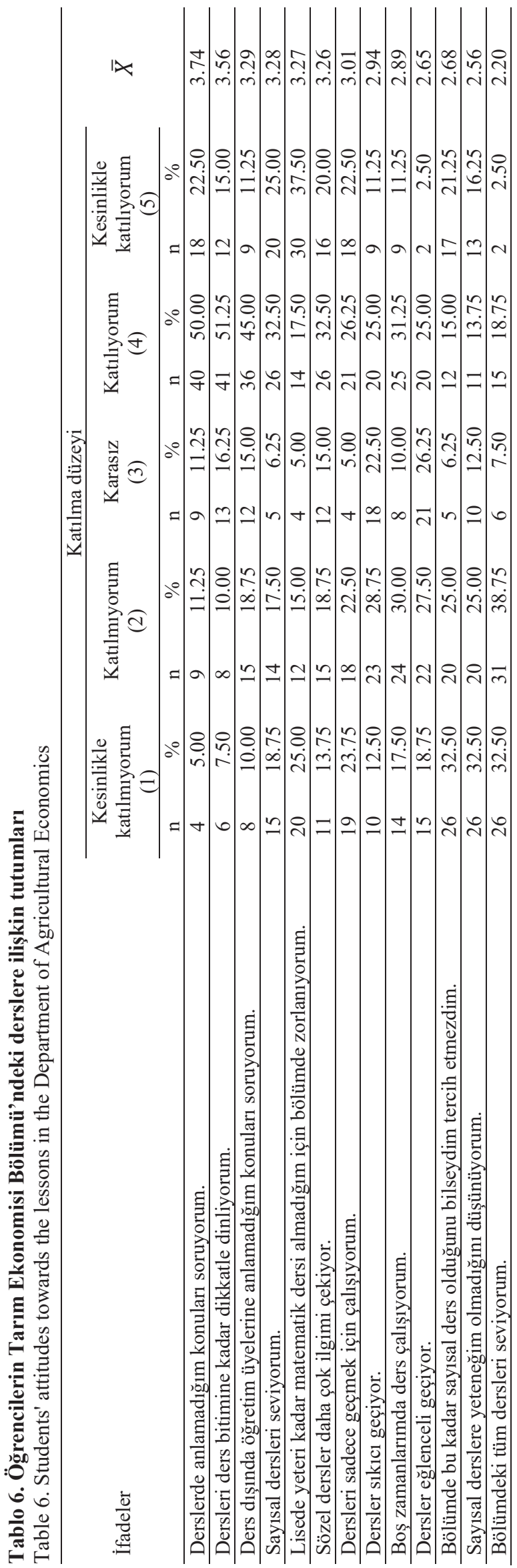




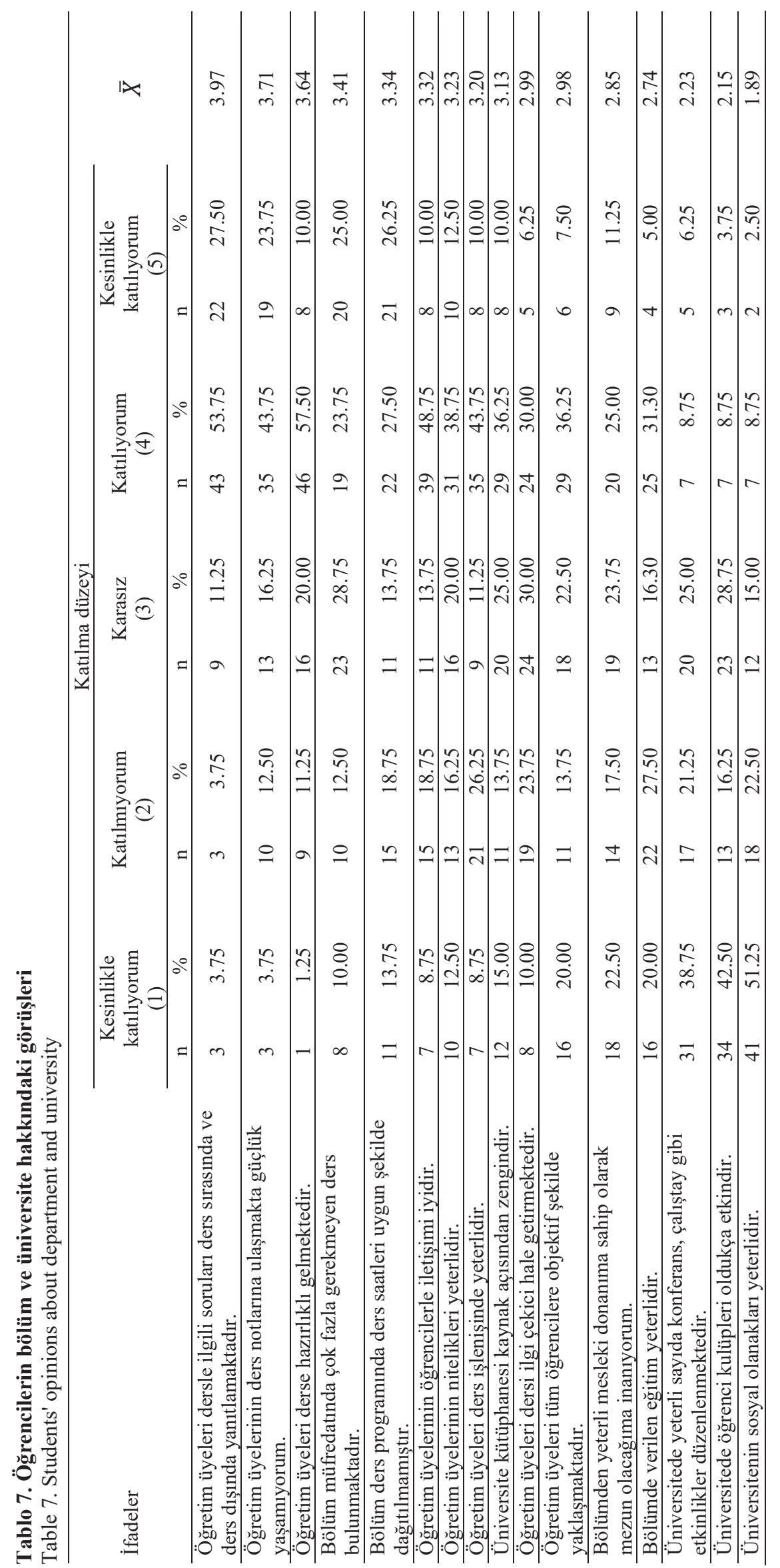


Tablo 8. Lojistik regresyon analizi sonuçları Table 8. Results of logistic regression analysis

\begin{tabular}{|c|c|c|c|c|c|}
\hline Değișkenler & Katsay 1 & Standart hata & Wald istatistiği & p değeri & Odds oran 1 \\
\hline Sabit terim & -6.783 & 3.563 & 3.625 & $0.057^{*}$ & 0.001 \\
\hline $\mathrm{C} 1$ & 1.223 & 0.933 & 1.720 & 0.190 & 3.398 \\
\hline $\mathrm{C} 3$ & 1.817 & 0.612 & 8.830 & $0.003^{* *}$ & 6.154 \\
\hline $\mathrm{C} 4$ & 0.878 & 0.356 & 6.094 & $0.014^{* *}$ & 2.406 \\
\hline $\mathrm{C} 5$ & -0.271 & 0.202 & 1.800 & 0.180 & 0.763 \\
\hline $\mathrm{C} 10$ & -0.549 & 0.336 & 2.679 & 0.102 & 0.577 \\
\hline $\mathrm{C} 11$ & 0.435 & 0.305 & 2.038 & 0.153 & 1.545 \\
\hline $\mathrm{C} 12$ & 1.389 & 0.807 & 2.966 & $0.085^{*}$ & 4.011 \\
\hline C19 & -2.159 & 0.986 & 4.794 & $0.029^{* *}$ & 0.115 \\
\hline C30 & 1.004 & 0.877 & 1.312 & 0.252 & 2.730 \\
\hline Nagelkerke $\mathrm{R}^{2}$ & & & & & 0.439 \\
\hline Cox ve Snell $\mathrm{R}^{2}$ & & & & & 0.283 \\
\hline -2 log likehood & & & & & 56.121 \\
\hline $\begin{array}{l}\text { Hosmer ve } \\
\text { Lemeshow testi }\end{array}$ & & & & & $\mathrm{p}=0.812$ \\
\hline Omnibus testi & & & & & $p=0.002$ \\
\hline
\end{tabular}

Tablo 9. Lojistik regresyon analizi sınıflama tablosu

Table 9. Classification table of logistic regression analysis

\begin{tabular}{|c|c|c|c|c|}
\hline \multirow{2}{*}{ Sinıflama } & & \multicolumn{3}{|c|}{ Tahmin } \\
\hline & & \multicolumn{2}{|c|}{ Başarı durumu } & \multirow{2}{*}{$\begin{array}{c}\text { Doğru sinıflama } \\
(\%)\end{array}$} \\
\hline Gözlem & & Başarılı & Başarısız & \\
\hline \multirow{2}{*}{ Başarı durumu } & Başarılı & 7 & 10 & 41.2 \\
\hline & Başarısız & 5 & 58 & 92.1 \\
\hline Toplam & & 12 & 68 & 81.3 \\
\hline
\end{tabular}

anlamlı olduğu tespit edilmiştir. Sınıf değişkeni Odds oranı 6.154'dür. Buna göre sınıf düzeyi arttıkça başarılı olma olasılığı artmaktadır. Sınıf düzeyinde 1 birimlik artış başarılı olma olasılığını 6.154 kat arttırmaktadır (Tablo 8). Bu sonucun ortaya çıkmasında üçüncü sınıf öğrencilerinin geçme notunun daha yüksek olmasının etkili olduğu düşünülmektedir. Aynı bulgu, Karagöz (2010) tarafından yapılan araştırmada da elde edilmiştir. Modelde yer alan diğer bir değişken olan barınma yeri, öğrencilerin başarı durumunu \% 5 anlam düzeyinde ve pozitif yönde etkilemektedir. Odds oranı 2.406'dır. Buna göre aile yanında kalanların başarılı olma olasılı̆̆ 2.406 kat fazladır (Tablo 8). Toprak ve ark. (2017) tarafindan yapılan çalışmada, yurtta kalan öğrencilerin daha başarılı olduğu sonucuna ulaşılmıştır. Karagöz (2010) tarafından yapılan çalışmada ise barınma yeri ile başarı durumu arasında anlamlı ilişki bulunamamıştır. Lojistik regresyon modelindeki $\mathrm{C} 12$ değişkeninin katsayısı pozitif ve Odds oran1 4.011 'dir. Ailesi tarımla uğraşanların başarılı olma olasılığının 4.011 kat fazla olduğu söylenebilir. Araştırmada elde edilen lojistik regresyon modelinde istatistiksel olarak anlamlı bulunan değişkenlerden olan derslere devam durumu incelendiğinde, öğrencilerin derslere devam etmemesinin başarılarını negatif yönde etkilediği saptanmıştır (Tablo 8). Katsayıları negatif ve Odds oranı değerleri sıfır (0)'a yakın olarak tahmin edilen değişkenlere ilişkin yorum yapılabilmesi için Odds oranı değerlerinin 1/Odds oranı olarak düzeltilmesi gerekir (Hosmer ve Lemeshow, 2000). C19 değişkenin katsayısı negatif ve Odds oranı 0.115 olduğu için düzeltme yapmak gerekir. Düzeltilmiş Odds oranı 1/0.115=8.69'dur. Buna göre öğrencilerin derslere devam etmemesi başarılı olma olasılığını 8.69 kat azaltmaktadır. Karagöz (2010) ve Rençber (2012) tarafindan yapılan çalışmalarda da benzer bir biçimde öğrenci başarısı ile derse devam sayısı arasında yüksek bir ilişki olduğu tespit edilmiştir.

\section{Sonuçlar}

Araştırma sonuçlarına göre, öğrencilerin çoğu ilk tercihi ile ve isteyerek bölüme gelmiştir. Bölüm tercihlerinde çoğunlukla ailelerinin etkili olduğu saptanmıştır. Ayrıca, öğrencilerin çoğunluğu bölümünden memnun olmakla birlikte, baz1 öğrencilerin üniversite koşullarından ve üniversitenin bulunduğu ilden memnun olmadıkları belirlenmiştir. Bununla birlikte, öğrenciler öğretim üyelerinin dersi çekici hale getirmediğini, yeterli mesleki donanımla mezun olamayacaklarını, üniversitenin yeterli etkinlikler düzenlemediğini ve sosyal olanakların yetersiz olduğunu düşünmektedirler. Öğretim üyeleri tarafından 
derslerde kullanılan materyallerin öğrencilerin dikkatini çekecek şekilde hazırlanması, bireysel farklılıkların göz önüne alınması, yenilikçi öğrenme ortamlarının kullanılması öğrencilerin başarılarının artmasına katkı sağlayacaktır.

Diğer taraftan, öğrencilerin büyük çoğunluğu Tarım Ekonomisi Bölümü'ndeki sayısal ders sayısının fazla olduğunu bilmediğini, sözel derslerin daha çok ilgisini çektiğini ve yeterli matematik altyapısı olmadığını belirtmiştir. Öğrencilerin lise eğitiminde yeterli eğitimi almadıkları takdirde üniversite eğitiminde sorun yaşadıkları söylenebilir. Bu nedenle lise eğitiminin önemi ve özellikle sayısal derslerin yer aldığ1 bölümleri tercih etmek isteyen öğrencilere sayısal derslerin önemi anlatılmalıdır. Ayrıca, öğrencilerin yetenek ve ilgi alanlarına göre tercih yapmas1, üniversite eğitiminde daha istekli ve dolayısıyla daha başarılı olmalarını sağlayabilir. Ailelerin bu konuda rehber öğretmenler aracılığıyla bilinçlendirilmesi oldukça önemlidir.

Araştırmada lojistik regresyon analizinden elde edilen sonuçlara göre öğrencilerin akademik başarısını sınıf düzeyi, barınma yeri, ailenin tarımla uğraşma durumu ve devam durumu etkilemektedir. Sınıf düzeyi arttıkça, ailesinin tarımla uğraşması durumunda ve öğrenci aile yanında kaldığında başarılı olma olasılığı artmaktadır. Öğrencilerin derslere devam etmemesi ise başarılarını negatif yönde etkilemektedir. Üniversite içinde öğrencilerin vakit geçireceği alanlar sınırlıdır. Üniversitenin sosyal olanaklarının çoğaltılması, kültürel faaliyetlerinin çeşitlendirilmesi gerekmektedir. Bu durum öğrencileri ruhsal açıdan olumlu etkileyerek motivasyonlarını artıracaktır ve derslere devam sayısını çoğaltabilecektir. Unvan değişikliği amacıyla Siirt Üniversitesi Tarım Ekonomisi Bölümü'ne gelen öğrenci sayısı oldukça fazladır. Bu öğrenciler çalıştıkları için devamsızlık sorunu yaşamaktadır. Devamsızlığın öğrenci başarısını etkilediği, bu araştırmada ve daha önce yapılan araştırmalarda da ortaya konulmuştur. Dolayısıyla öğrencilerin bu konuda bilgilendirilmesi ve yöneticilerin çalışanlarına ders devamı açısından kolaylık sağlaması büyük önem taşımaktadır.

Öğrencilerin ailesinin tarımla uğraşması durumunda başarılı olma olasılığının arttığ belirlenmiştir. $\mathrm{Bu}$ nedenle tarım sektörüne yabancı olan öğrencilerin mesleklerini yakından tanıması açısından Ziraat Fakültesinde tarım ile ilgili çeşitli etkinliklerin (seminer, konferans, vs.) düzenlenmesi, Tarım ve Orman Bakanlığ İl Müdürlüğü, Ziraat Odası gibi tarımla ilgili kuruluşların öğrencilere tanıtılması yararlı olacaktır. Özellikle birinci sınıftaki öğrencilerin bu tür faaliyetlere katılması teşvik edilmelidir.

\section{Kaynaklar}

Ağır, H.B., Akbay, C., Yılmaz, H.İ., 2016. Ziraat Fakültesi öğrencilerinin öğrenim başarısını etkileyen faktörler: Kahramanmaraş Sütçü İmam Üniversitesi Örneği. Kahramanmaraş Sütçü İmam Üniversitesi Doğa Bilimleri Dergisi, 19(4): 425-432.

Akbulut, R., Rençber, Ö.F., 2015. Veri zarflama ve lojistik regresyon analizi ile çimento işletmelerinde finansal performansa dayalı etkinliklerin değerlendirilmesi. Uluslararası Alanya Issletme Fakültesi Dergisi, 7(3): 123-135.

Bahar, H.H., Özen, Y., Gülaçtı, F., 2009. Eğitim Fakültesi öğrencilerinin cinsiyet ve branșa göre akademik başarı durumları ile öğrenme stillerinin incelenmesi. Ankara Üniversitesi Eğitim Bilimleri Fakültesi Dergisi, 42(1): 69-86.

Başaran, B., Tengiz, Z.M., Oraman, Y., 2019. Ziraat Fakültesi öğrencilerinin tarımın geleceğine yönelik bakış açıları: Tekirdağ ili örneği. International Conference on Eurasian Economies, 11-13 Haziran, Gazimağusa, Kuzey Kıbrıs Türk Cumhuriyeti, s. 294301.

Can, Ş., Özdil, T., Y1lmaz, C., 2018. Üniversite ögrencilerinin ders başarısını etkileyen faktörlerin lojistik regresyon analizi ile tahminlenmesi. International Review of Economics and Management, 6(1): 28-49.

Çırak, G., 2012. Yükseköğretimde öğrenci başarılarının sınıflandırılmasında yapay sinir ağları ve lojistik regresyon yöntemlerinin kullanılması. Yüksek Lisans Tezi, Ankara Üniversitesi Eğitim Bilimleri Enstitüsü, Ankara.

Çokluk, Ö., 2010. Lojistik regresyon analizi: kavram ve uygulama. Kuram ve Uygulamada Eğitim Bilimleri, 10(3): 1357-1407.

Demir, A., Pala, A., Baytekin, H., 2006. Ziraat Fakülteleri öğrencilerinin sosyal yapıları, eğilimleri ve sorunları üzerinde bir araştırma. Tekirda $\breve{g}$ Ziraat Fakültesi Dergisi, 2(3): 259-267.

Demir, N., Kadanal, E., Ertek, N., Dağdemir, V., 2014. Tarım Ekonomisi öğrencilerinin bölüm tercihlerinde etkili olan faktörlerin belirlenmesi üzerine bir çalışma. XI. Ulusal Tarım Ekonomisi Kongresi, 3-5 Eylül, Samsun, s. 531-536.

Engindeniz, S., Özden, F., 2009. Ege Üniversitesi Ziraat Fakültesi Öğrencilerinin Girişimcilik Eğilimlerinin Saptanması Üzerine Bir Araştırma. İzmir Genç İşadamları Derneği Yayınları, Yayın No: 1, İzmir.

Girginer, N., Cankuş, B., 2008. Tramvay yolcu memnuniyetinin lojistik regresyon analiziyle ölçülmesi: Estram örneği. Yönetim ve Ekonomi, 15(1): 181-193.

Gujarati, N.D., 1992. Essentials of Econometrics. McGraw Hill, New York.

Hosmer, D. W., Lemeshow, S., 2000. Applied Logistic Regression. John Wiley \& Sons, New York. 
Karadaş, K., Ertürk, Y.E., Şahin, K., Karadağ Gürsoy, A., 2016. Iğdır Üniversitesi Ziraat Fakültesi Tarım Ekonomisi Bölümü öğrencilerini işsizlik kaygıları üzerine bir araştırma. XII. Ulusal Tarım Ekonomisi Kongresi, 25-27 May1s, Isparta, s. 1635-1641.

Karagöz, Y., 2010. İlişki katsayıları ile öğrenci başarısını etkileyen faktörlerin belirlenmesi. Elektronik Sosyal Bilimler Dergisi, 32(9): 425-446.

Kızılaslan, N., Kızıloğlu, R., Ünal, T., Çakır, T., Hanedar, C., Kızılaslan, H., 2017. Ziraat Fakültesi ögrencilerinin meslekten beklentilerinin Gaziosmanpaşa Üniversitesi örneğinde incelenmesi. Gaziosmanpaşa Üniversitesi Ziraat Fakültesi Dergisi, 34 (1): 1-14.

Özcan, B., Güler, E., Yerlikaya, Z., 2017. Kocaeli Mühendislik Fakültesi mezunlarının akademik başarılarının incelenmesi. Kocaeli Üniversitesi Sosyal Bilimler Dergisi, 34: 143-168.

Özgüven, İ.E., 1974. Üniversite Öğrencilerinin Akademik Başarılarını Etkileyen Zihinsel Olmayan Faktörler. Hacettepe Üniversitesi Basımevi, Ankara.

Rençber, B.A., 2012. Üniversite öğrencilerinin akademik başarılarını etkileyen faktörler. Çankırı Karatekin Üniversitesi Sosyal Bilimler Enstitüsü Dergisi, 3(1): 191-198.
Sarıhan, E.O., Arslan Duru, A., Parlakay, O., 2015. Uşak Üniversitesi Ziraat ve Doğa Bilimleri Fakültesi öğrenci profili ve sosyo-ekonomik yapısı. Mustafa Kemal Üniversitesi Ziraat Fakültesi Dergisi, 20(2): 52-59.

Sezgin, A., Erem, T., Aksoy, A., 2008. Atatürk Üniversitesi Ziraat Fakültesi öğrencilerin sosyoekonomik durumları ve genel eğilimlerinin belirlenmesi üzerine bir araștırma. Atatürk Üniversitesi Ziraat Fakültesi Dergisi, 39(1): 1-8.

Sezgin, A., Yavuz, F., 2008. Ziraat eğitiminde başarıya etki eden faktörlerin analizi: Atatürk Üniversitesi örneği. Tarım Ekonomisi Dergisi, 14(2): 87-94.

Topçu, Y., Uzundumlu, A.S., 2012. Yüksek öğretimde öğrencilerin başarısızlığına etki eden faktörlerin analizi. Iğdır Üniversitesi Fen Bilimleri Enstitüsü Dergisi, 2(Ek A): 51-58.

Toprak, İ.B., Doğdu, N., Öztürk, M., 2017. Meslek yüksekokullarında akademik başarıya etki eden faktörler: Akdeniz Üniversitesi Teknik Bilimler Meslek Yüksekokulu örneği. Cankırı Karatekin Üniversitesi Sosyal Bilimler Enstitüsü Dergisi, 8(1): 150-163. 